Jurnal Elektro Luceat [Juli] [2020]

\title{
RANCANG BANGUN PROTOTIPE ALAT PENGHITUNG PRODUK SECARA OTOMATIS DENGAN KONSEP INTERNET OF THING (IOT) BERBASIS MIKROKONTROLLER (ARDUINO UNO)
}

\author{
Sepriandi Parningotan ${ }^{1}$, Tri Mulyanto ${ }^{2}$ \\ ${ }^{1}$ Universitas Gunadarma \\ ${ }^{2}$ Universitas Gunadarma \\ ${ }^{1}$ sepriandi.p@student.gunadarma.ac.id, ${ }^{2}$ tri mulvanto@staff.gunadarma.ac.id
}

\begin{abstract}
Abstrak
Perkembangan teknologi telah merubah industri khususnya manufaktur menjadi sebuah industri yang harus dapat berkembang dan bersaing secara global lewat konvergensi teknologi informasi. Sektor industri memerlukan inovasi terutama dalam aspek penguasaan teknologi yang menjadi kunci penentu daya saing di era Industri 4.0. IoT merupakan alat yang saling terintegrasi dan dapat digunakan dalam Era Industri 4.0. Berdasarkan permasalahan yang terjadi, maka perlu untuk melakukan penelitian dan membuat suatu alat sebagai pengembangan teknologi pada sistem manajemen gudang berbasis internet of thing menggunakan mikrokontroller. Dengan adanya sistem alat ini kegiatan menerima dan mengirim barang dapat terdeteksi jumlahnya dan data produk secara otomatis masuk kedalam database secara cepat dan tepat serta memungkinkan satu perangkat berbicara dengan perangkat lainnya sehingga pencatatan, pelacakan, serta pergerakan barang bisa dilakukan secara terintegrasi. Kesimpulan dari penulisan ini adalah alat ini secara otomatis akan menghitung produk dan memasukkan maupun mengeluarkan produk dengan cara melakukan pemindaian kode QR. Berdasarkan hasil pengujian maka didapatkan QRCode Scanner berhasil terpindai dengan jarak maksimal sejauh $25 \mathrm{~cm}$. Sensor dapat mendeteksi objek sejauh 60 $\mathrm{cm}$. Pada pencahayaan sangat terang, terang dan redup kode QR berhasil dilakukan proses pemindaian oleh scanner. Pada jangkauan jarak koneksi bluetooth dapat dikendalikan sepenuhnya dengan jarak maksimal $160 \mathrm{~cm}$.
\end{abstract}

Kata kunci : Internet of Thing (IoT), Mikrokontroler, Arduino Uno.

\begin{abstract}
The development of technology has changed the industry, especially manufacturing, into an industry that must be able to develop and compete globally through the convergence of information technology. The industrial sector requires innovation, especially in the aspect of mastery of technology which is a key determinant of competitiveness in the Industrial 4.0 era. IoT is a mutually integrated tool and can be used in the Industrial Age 4.0. Based on the problems that occur, it is necessary to conduct research and make a tool as a technology development in the internet-based warehouse management system of things using a microcontroller. With this tool system the activity of receiving and sending goods can be detected in quantity and product data automatically entered into the database quickly and precisely and allows one device to talk with other devices so that the recording, tracking, and movement of goods can be done in an integrated manner. The conclusion from this writing is that this tool will automatically count the products and enter or remove the product by scanning the QR code. Based on the test results, QRCode Scanner was successfully scanned with a maximum distance of $25 \mathrm{~cm}$. The sensor can detect objects as far as $60 \mathrm{~cm}$. In very bright lighting, bright and $\operatorname{dim}$ QR code scanning process is successfully carried out by the scanner. In the range of distance the Bluetooth connection can be fully controlled with a maximum distance of $160 \mathrm{~cm}$.
\end{abstract}

Kata kunci : Internet of Thing (IoT), Mikrokontroler, Arduino Uno. 
Jurnal Elektro Luceat [Juli] [2020]

\section{PENDAHULUAN}

Perkembangan teknologi telah merubah industri khususnya manufaktur menjadi sebuah industri yang harus dapat berkembang dan bersaing secara global serta berdampak pada revolusi industri. Revolusi industri pertama berbicara tentang terciptanya mesin uap, lalu pada revolusi industri kedua ditandai terjadinya perbaikan proses produksi yang membuat manusia dapat memproduksi barang secara massal (mass production) pada abad ke-19. Setelah itu muncul revolusi industri ketiga yaitu automasi produksi menggunakan robot dan penggunaan teknologi informasi. Masuk kepada revolusi industri keempat, menekankan kepada integrasi antar alat menggunakan internet dan pemanfaatan big data. Perkembangan teknologi yang agresif ini juga berimbas pada sektor industri. Revolusi ini akan ditandai dengan semakin eratnya keterkaitan antara manusia, mesin, dan sumber daya alam lewat konvergensi teknologi informasi. Era Industri 4.0 juga akan menjadi jembatan antara dunia digital dengan sektor industri. Salah satu faktor pendukung utama untuk mengimplementasikan industri 4.0 adalah ketersediaan infrastruktur digital. Adapun lima teknologi digital sebagai fundamental yang dapat menopang pembangunan sistem Industri 4.0, yaitu Internet of Things, Artificial Intelligence, Human-Machine Interface, teknologi robotik dan sensor, serta teknologi 3D Printing.

Internet untuk segala internet atau Internet of Thing (IoT) merupakan alat yang terhubung dengan internet dan saling terintegrasi yang telah dimanfaatkan di industri dan merupakan suatu konsep dimana objek tertentu punya kemampuan untuk mentransfer data lewat jaringan tanpa memerlukan adanya interaksi dari manusia ke manusia ataupun dari manusia ke perangkat komputer. Pada dunia manufaktur modern, industri dilengkapi dengan teknologi seperti mesin dan alat yang kompatibel dengan IoT, dimana IoT dapat digunakan sebagai penghubung antar mesin produksi maupun peralatan pendukung lainnya agar berjalan dengan efisisen, selain itu sebagai pemantauan alur produksi dan logistik agar memiliki manajemen yang lebih baik.

Bagian pengiriman maupun gudang terdapat adanya beberapa masalah yang meliputi tiga aktivitas utama gudang yaitu proses penerimaan, penyimpanan, dan pengiriman. Pada proses penerimaan dan pengiriman barang, terdapat masalah yang disebabkan karena kelalaian para operator yang salah dalam menginput barang jadi dan barang yang akan dikirim ke komputer, khususnya menginput code yang menjadi acuan terhadap produk. Hal ini mengganggu pada proses pengecekan yang masuk dengan hasil penginputan barang tersebut dan dapat menyebabkan kesalahan dalam pengiriman barang. Proses tersebut dapat menyebabkan terjadinya delay yang dimulai dari proses produk jadi yang di suplai ke lini penyimpanan hingga pengiriman. Proses delay ini kerap kali disebabkan karena operator membutuhkan beberapa waktu untuk menginput data. Secara otomatis, permasalahan ini akan menimbulkan berbagai dampak dalam segi biaya dan waktu. Berdasarkan permasalahan yang terjadi, maka penulis tertarik untuk melakukan penelitian dan membuat suatu alat pada Sistem manajemen gudang berbasis internet of thing menggunakan mikrokontroller". Dengan adanya sistem alat ini Kegiatan menerima dan mengirim barang dapat terdeteksi jumlahnya dan data produk secara otomatis masuk kedalam database secara cepat dan tepat serta memungkinkan satu perangkat berbicara dengan perangkat lainnya sehingga pencatatan, pelacakan, serta pergerakan barang bisa dilakukan secara terintegrasi.

\section{DASAR TEORI /MATERIAL DAN METODOLOGI/PERANCANGAN}

\subsection{Sejarah Revolusi Industri}

Sejarah revolusi industri dimulai dari industri 1.0, 2.0, 3.0, hingga industri 4.0. Fase industri merupakan real change dari perubahan yang ada. Industri 1.0 ditandai dengan mekanisasi produksi untuk menunjang efektifitas dan efisiensi aktivitas manusia, industri 2.0 dicirikan oleh produksi massal dan standarisasi mutu, industri 3.0 ditandai dengan penyesuaian massal dan fleksibilitas manufaktur berbasis otomasi dan robot. Industri 4.0 selanjutnya hadir menggantikan industri 3.0 yang ditandai dengan cyber fisik dan kolaborasi manufaktur ${ }^{[1]}$.

RANCANG BANGUN PROTOTIPE ALAT PENGHITUNG PRODUK SECARA OTOMATIS DENGAN KONSEP INTERNET OF THING (IOT) BERBASIS MIKROKONTROLLER (ARDUINO UNO) 
Jurnal Elektro Luceat [Juli] [2020]

Industri 4.0 ditandai dengan peningkatan digitalisasi manufaktur yang didorong oleh empat faktor: 1) peningkatan volume data, kekuatan komputasi, dan konektivitas; 2) munculnya analisis, kemampuan, dan kecerdasan bisnis; 3) terjadinya bentuk interaksi baru antara manusia dengan mesin; dan 4) perbaikan instruksi transfer digital ke dunia fisik, seperti robotika dan 3D printing ${ }^{[2]}$. Prinsip industri 4.0 memiliki empat desain, yaitu Pertama, interkoneksi (sambungan) yaitu kemampuan mesin, perangkat, sensor, dan orang untuk terhubung dan berkomunikasi satu sama lain melalui Internet of Things (IoT) atau Internet of People (IoP) ${ }^{[3]}$. Internet of Things (IoT) adalah ketika kita menyambungkan sesuatu (things) yang tidak dioperasikan oleh manusia ke internet ${ }^{[4]}$.

\subsection{Metode, Alat dan Bahan}

Metode eksperimen dilakukan dengan perancangan alat untuk menghitung produk secara otomatis dengan konsep Internet of Things (IOT) menggunakan pengendali mikro ${ }^{[5]}$. Data yang akan diambil juga diperoleh melalui metode eksperimen. Alat yang dibuat diharapkan dapat menghitung jumlah produk yang akan disimpan maupun dikirim secara otomatis dan mendeteksi kesesuaian produk. Pada objek penelitian ini, peneliti dapat mengamati secara mendalam aktivitas (activity) orang-orang (actors) yang ada pada tempat (place) tertentu. Dalam proses pembuatan alat ini menggunakan beberapa alat dan bahan, yaitu :

1. Perangkat Keras (Hardware)

Perangkat keras adalah sebuah komponen fisik pada komputer yang digunakan oleh sistem untuk menjalankan perintah yang telah diprogramkan. Perangkat keras adalah semua perlengkapan fisik yang dapat dilihat, terdiri dari perangkat masukan dan keluaran komunikasi (modem), yang digunakan untuk melaksanakan bermacam-macam fungsi dan seluruh kegiatan pengolahan data.

2. Perangkat Lunak (Software)

Perangkat lunak adalah program yang berisi instruksi-instruksi untuk melakukan pengolahan data. Perangkat Lunak Sistem Operasi (operating software) dan Perangkat Lunak Aplikasi (application software). Perangkat lunak sering disebut sebagai program komputer yang memuat instruksi-instruksi yang dibutuhkan oleh mesin fisik/hardware untuk melengkapi tugas-tugas yang diperlukan.

\subsection{Perangkat Keras dan Perangkat Lunak}

Berikut ini adalah beberapa perangkat keras yang digunakan untuk perancangan sistem pada penelitian ini, diantaranya :

1. Mikrokontroler arduino, sebagai pengolah perintah dari sensor dan digunakan untuk kendali peralatan elektronik ${ }^{[6]}$.

2. Sensor ultrasonic, yang biasa di sebut dengan transduser ultrasonik, sebagai pendeteksi keberadaan suatu objek tertentu di depannya.

3. Bluetooth, sebagai komunikasi baik antar dua sistem pengendali mikro mauoun antara suatu sistem ke device lain, misalnya antara android dan pengendali mikro.

4. Kabel dan Arduino Konektor USB, sebagai koneksi data ke komputer/laptop dimana penggunaan untuk pemrograman Arduino UNO.

5. PCB / Project Board, digunakan untuk meletakkan rangkaian elektronika dan menghubungkannya untuk sementara sesuai dengan letaknya yaitu secara horizontal maupun vertikal. 


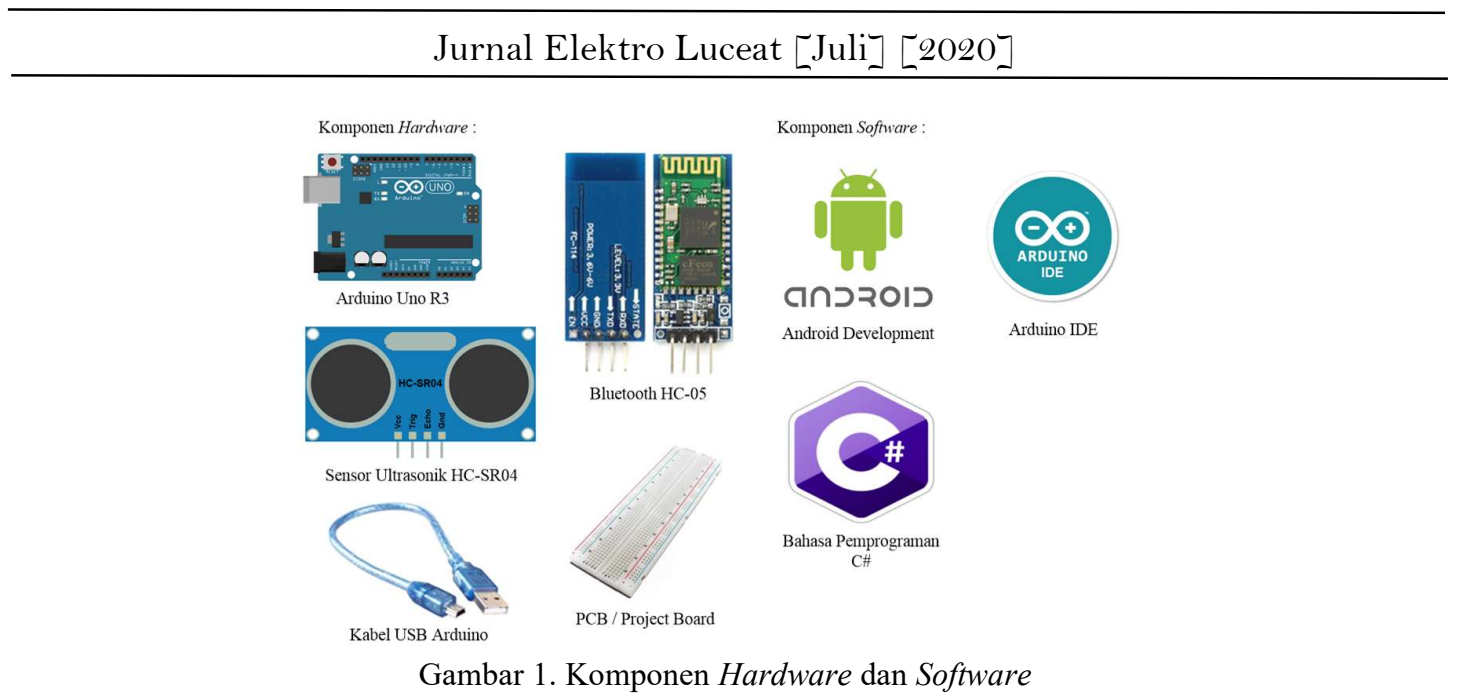

Berikut ini adalah beberapa perangkat lunak yang digunakan untuk perancangan system pada penelitian ini, diantaranya :

1. Android Development, digunakan untuk membuat aplikasi dan mengembangkan aplikasi berbasis android.

2. C\# Language, sebagai pemrograman server-side pada website dan membangun aplikasi desktop ataupun mobile.

3. Arduino Software (Integrated Developtment Enviroenment), sebagai text editor untuk membuat, mengedit, dan juga mevalidasi kode program. bisa juga digunakan untuk mengupload atau memprogram ke board Arduino ${ }^{[7]}$.

\subsection{Blog Diagram}

Dalam membuat sebuah alat penghitung atau pengontrol produk pada produksi dan gudang penyimpanan maka diperlukan sebuah alur yang jelas dan gambaran umum sistem alat yang akan dibuat berdasarkan kebutuhan, sehingga dapat diketahui komponen sistem yang akan digunakan. Adapun diagram blok sistem yang akan dibuat adalah sebagai berikut.

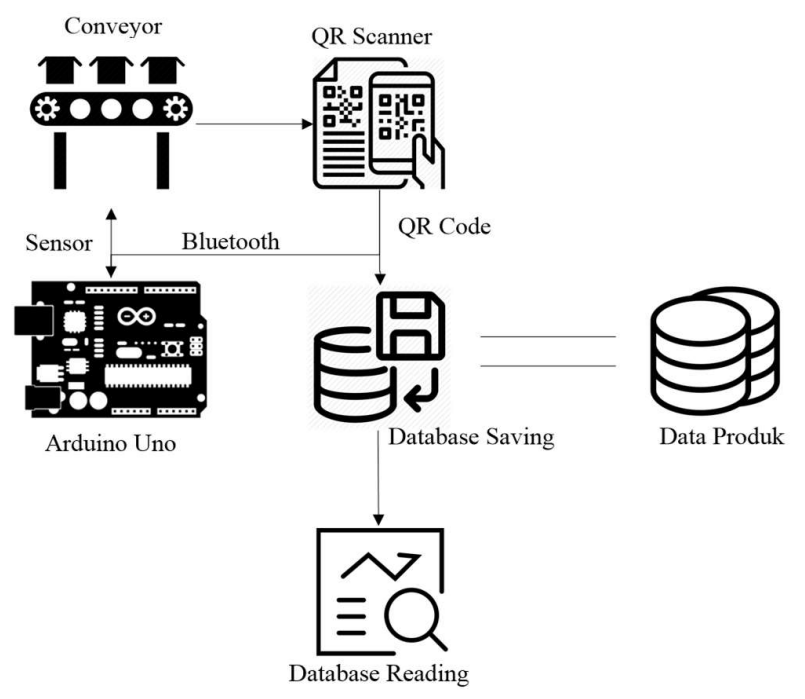

Gambar 2. Blog Diagram Rangkaian 
Pada Gambar 2 merupakan blog diagram rangkaian yang dibuat pada penelitian ini. Berdasarkan diagram blok diatas dapat dijelaskan bagaimana sistem yang akan dibuat membutuhkan suatu input data berupa quick response code scanner yang akan mendeteksi kode identitas produk yang akan masuk maupun keluar dari gudang penyimpanan. Selain itu juga dibutuhkan suatu perangkat bluetooth yang digunakan sebagai media komunikasi data untuk dapat mengendalikan arduino secara otomatis menggerakan conveyor ketika produk terscan oleh quick response code scanner. Conveyor pada dasarnya memiliki prinsip kerja untuk mentransport material yang ada diatas conveyor, sehingga pada penelitian ini conveyor berfungsi untuk mengantarkan produk secara otomatis. Pada saat sensor mendeteksi adanya objek maka tegangan output dari sensor akan masuk ke mikrokontroler, kemudian mikrokontroler melalui arduino akan memproses untuk mengaktifkan conveyor. Setelah semua input terpenuhi maka dibutuhkan sistem yang bisa diatur untuk mengeksekusi sebuah perintah.

\subsection{Flowchart Penelitian}

Penelitian merupakan kegiatan sistematis dengan serangkaian proses yang dilakukan secara terstruktur. Setiap tahapan proses tersebut akan saling berhubungan, dimana suatu proses yang dilakukan merupakan bagian dari tahapan yang menentukan proses selanjutnya. Dengan demikian perlu adanya suatu metodologi penelitian sebagai langkah untuk melakukan tahapan-tahapan tersebut secara teliti dan sistematis. Dalam ini penyelesaiannya dilakukan dengan beberapa tahapan proses. Tahapan proses tersebut digambarkan dalam flowchart metodologi penelitian dibawah ini.

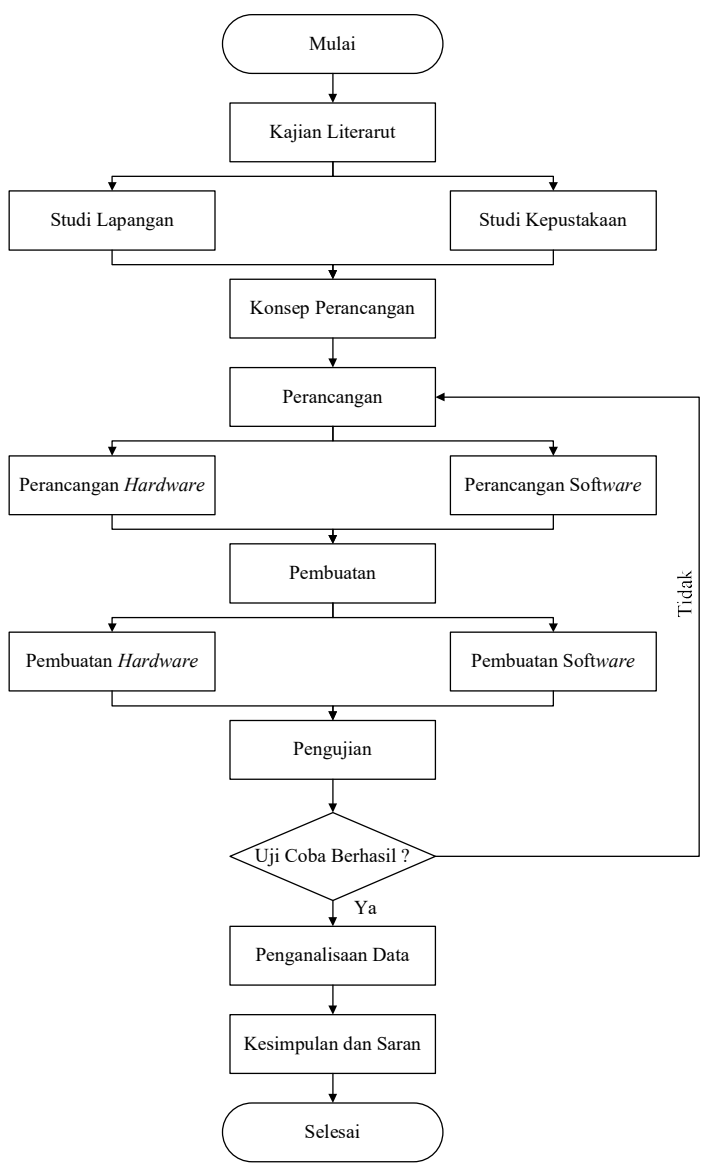

Gambar 3. Flowchart Penelitian 
Jurnal Elektro Luceat [Juli] [2020]

\section{PEMBAHASAN}

Penelitian ini dapat dibedakan menjadi dua, yaitu perangkat keras (hardware) dan perangkat lunak (software). Perangkat keras yang dihasilkan berupa perangkat yang dibuat atau dirancang dan diprogram dengan menggunakan aplikasi Arduino IDE, sedangkan perangkat lunaknya sebagai pendukung pada perangkat yang dirancang dan terdiri dari beberapa program maupun aplikasi.

Pembuatan perangkat keras merupakan pembuatan keseluruhan sehingga menjadi satu sistem. Perancangan perangkat keras ini tergambar dalam suatu diagram blok seperti yang terdapat pada Gambar 3 Perancangan dibuat untuk mengetahui fungsi tiap komponen penyusunan alat dan perancangan perangkat keras terdapat alat dan komponen yang mendukung sistem yang akan dirancang. Pada perancangan perangkat keras (hardware), ada beberapa komponen utama yang terdapat pada alat ini diantaranya adalah mikrokontroler arduino, sensor ultrasonic, bluetooth dan perangkat pendukung lainnya seperti driver motor L298N dan sebagainya. Penjelasan hasil pembuatan alat perangkat keras (hardware) adalah sebagai berikut:

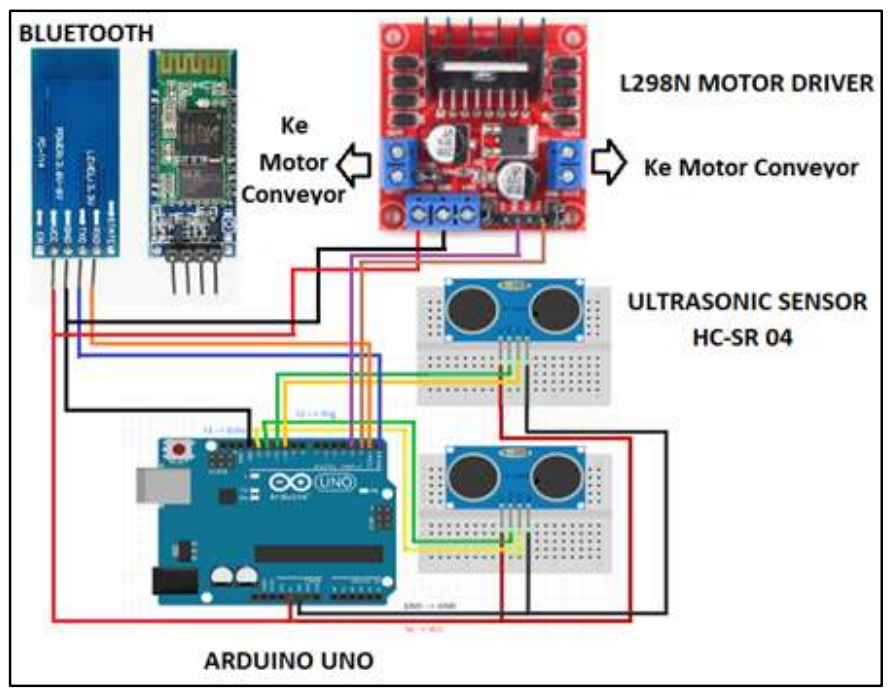

Gambar 4. Rangkaian Komponen Hardware

Pada perancangan alat ini, salah satu perangkat yang digunakan merupakan perangkat lunak. Perancangan perangkat lunak merupakan pendefinisian dari kebutuhan-kebutuhan fungsional dan persiapan untuk rancang bangun implementasi. Perangkat lunak ini berfungsi untuk mengatur kinerja keseluruhan dari sistem yang terdiri dari beberapa perangkat keras sehingga sistem ini dapat bekerja dengan baik. Desain sistem dapat di definisikan sebagai penggambaran, perencanaan dan pembuatan sketsa atau pengaturan dari beberapa elemen yang terpisah ke dalam satu kesatuan yang utuh dan berfungsi, meliputi diagram blok sistem dan alur sistem, perancangan user interface, dan perancangan database.

Pada perancangan ini akan menggunakan board Arduino Uno. Board Arduino terdiri dari hardware/modul mikrokontroller yang siap pakai dan pemrogaman yang digunakan adalah software Arduino IDE. Kelebihan dari Arduino yaitu tidak direpotkan dengan rangkaian minimum sistem dan programmer karena sudah built in dalam satu board. Proses berikutnya adalah penulisan listing program. Listing program merupakan susunan dari beberapa struktur data / computer codes. Selanjutnya, susunan tersebut dapat disusun menjadi semacam perintah programming yang dapat digunakan dalam menyusun sebuah perintah pada software bahasa pemrogaman C. Berikut adalah 
sebagian dari listing program dari implementasi dan perancangan alat untuk menghitung produk secara otomatis dengan konsep Internet of Things berbasis mikrokontroler.

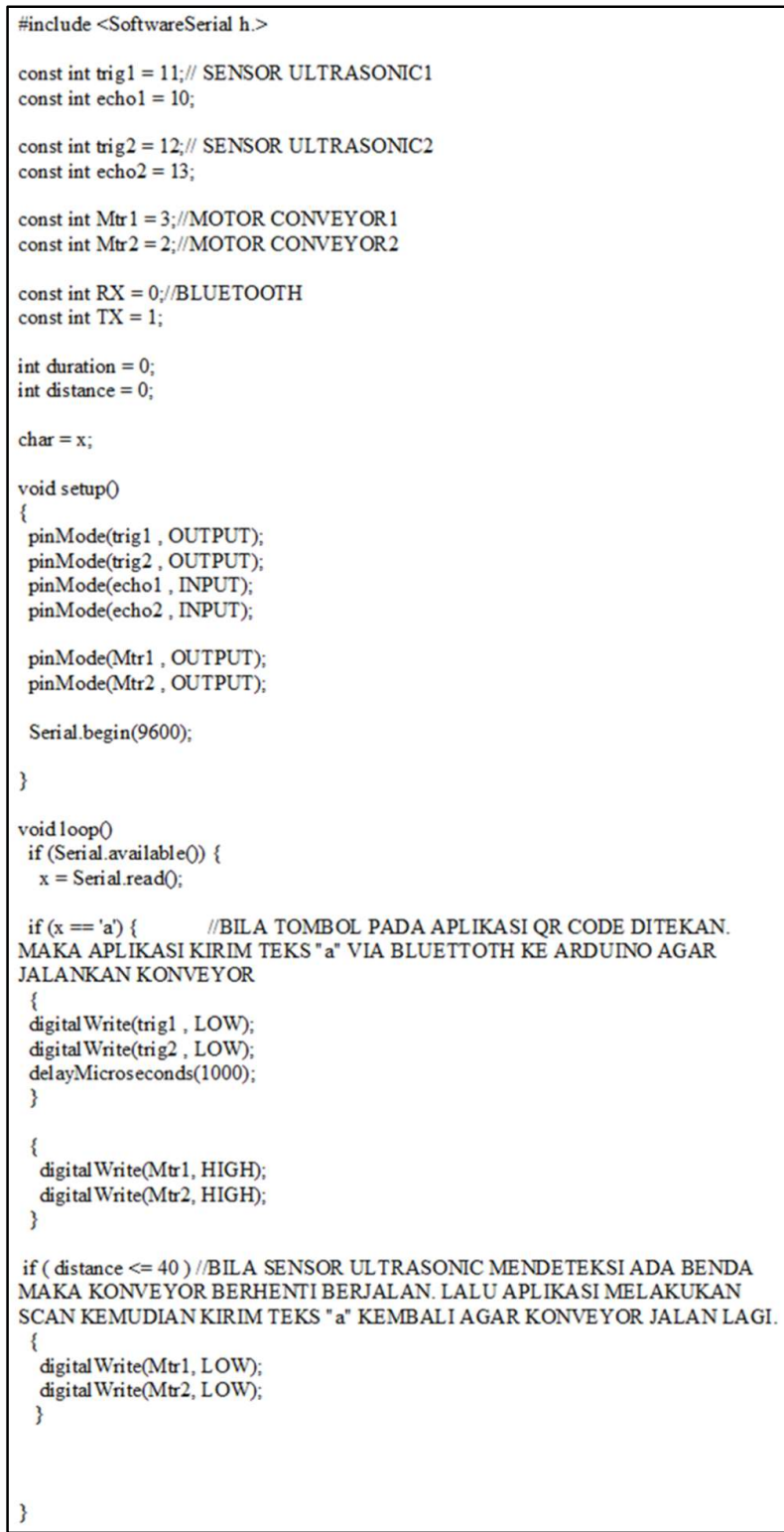

Gambar 5. Bagian Listing Program

Tahap selanjutnya pembuatan aplikasi QR Code Scanner adalah hasil dari tahap rancangan aplikasi yang telah dibangun yaitu yaitu berupa Kode QR Scanner. Perancangan sistem aplikasi QR Code Scanner menjelaskan alur kerja sistem, tabel relasi, hak akses pengguna dan admin disaat aplikasi sedang digunakan. Kode QR reader / scanner adalah perangkat untuk membaca kode-kode visual QRCarcode ${ }^{[8]}$. Hanya dengan menyapukan segaris sinar laser, ia dengan cepat membaca fragmen terang gelap pada barcodeyang tercetak di kertas dengan sangat cepat dan akurat.

Pada sistem aplikasi ini pengguna hanya memanfaatkan smartphone yang memiliki kamera dan mempunyai aplikasi pemindai kode QR. Tampilan Kode QR Scanner merupakan tampilan pada perangkat smartphone, berfungsi untuk mempermudah pada pengguna smartphone untuk 
mencari informasi tentang produk sehingga disaat pengguna sedang tidak berada pada bagian produksi tetap dapat memantau. Memperjelas keterangan diatas dapat dilihat pada gambar berikut.

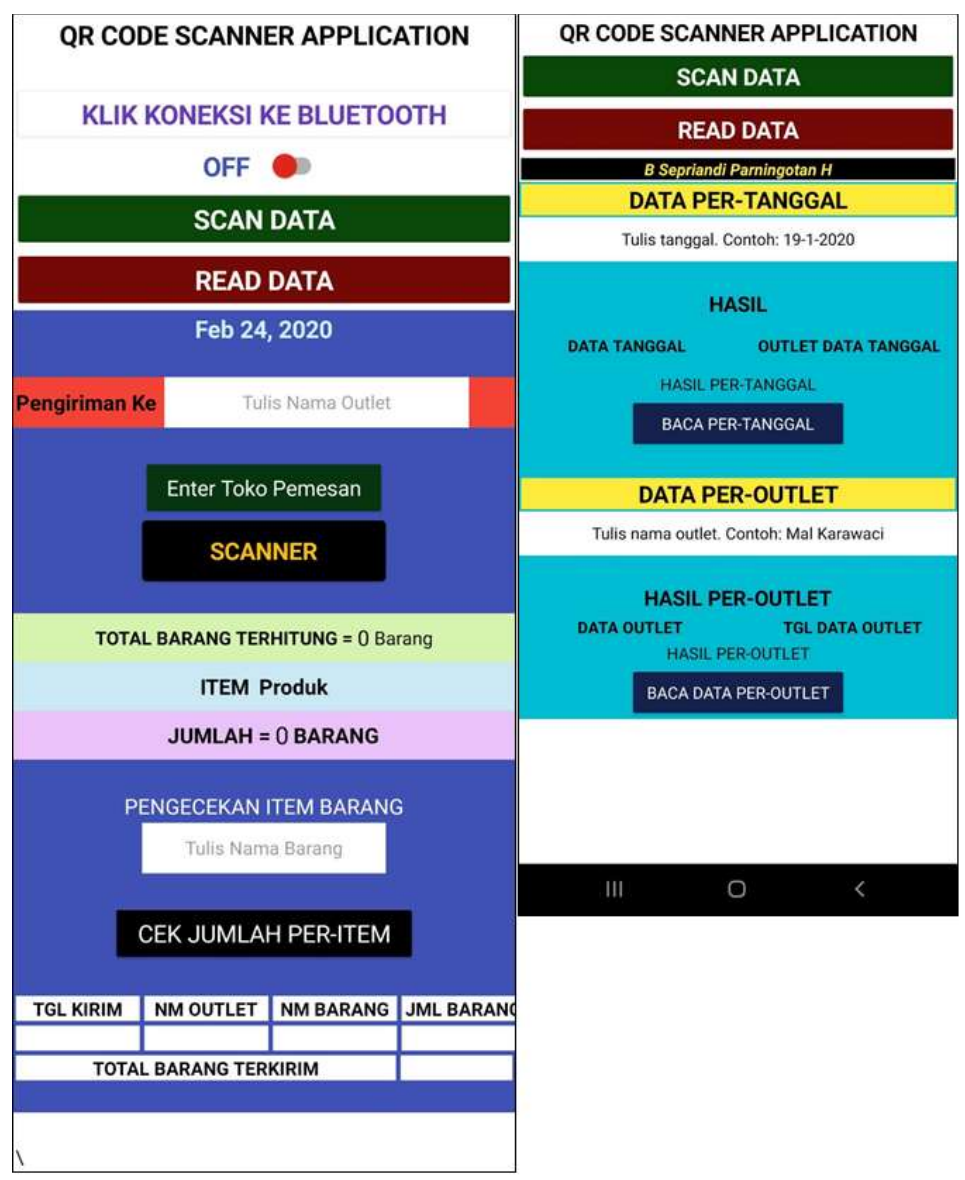

Gambar 6. Tampilan Aplikasi Kode QR Scanner

QR Code mempunyai dua sisi yang berisi data, dan ini membuat QR Code lebih banyak memuat informasi dibandingkan bar code. QR Code misalnya, dapat menampung informasi berupa Uniform Resource Locator (URL) suatu website yang nantinya dapat digunakan pada majalah, iklan, atau media lainnya. Sehingga ketika seorang pengguna handphone berkamera yang mempunyai aplikasi pembaca QR Code dapat langsung men- scan dan masuk ke website yang dimaksud tanpa perlu mengetikkan alamatnya. Kegunaan lain misalnya QR Code digunakan untuk menyimpan data teks mengenai informasi produk atau hal lain, SMS, atau informasi kontak yang mengandung nama, nomor telepon, dan alamat ${ }^{[9]}$.
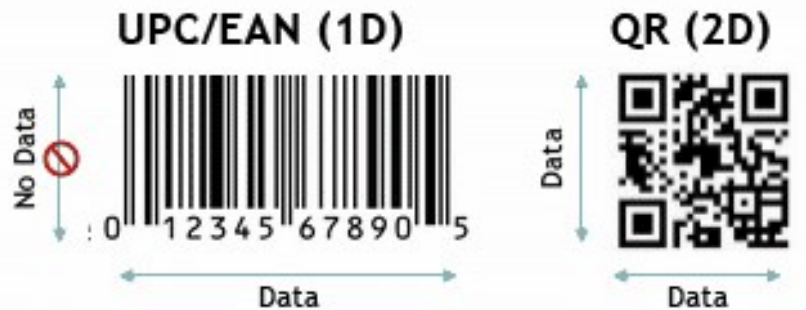

Gambar 7. QR Code dan Bar Code 
JEC Vol. 6 No. 1

Jurnal Elektro Luceat [Juli $]$ [2020]

\subsection{Hasil Pengujian Perangkat}

Pengujian perangkat keras dilakukan untuk mengetahui apakah perangkat keras yang telah dirancang dapat bekerja atau berfungsi dengan baik sebagaimana yang diinginkan. Pengujian yang dilakukan terhadap perangkat keras meliputi beberapa blok rangkaian perangkat keras yang telah dirancang. Data hasil pengujian jangkauan jarak koneksi Bluetooth HC-05, sebagai berikut:

Tabel 1. Pengujian Jarak Bluetooth

\begin{tabular}{|c|c|c|}
\hline Jarak $(\mathrm{cm})$ & Keterangan & Waktu (Detik) \\
\hline 20 & Terhubung & 5 \\
\hline 40 & Terhubung & 5 \\
\hline 60 & Terhubung & 6 \\
\hline 80 & Terhubung & 7 \\
\hline 100 & Terhubung & 8 \\
\hline 120 & Terhubung & 8 \\
\hline 140 & Terhubung & 9 \\
\hline 160 & Terhubung & 10 \\
\hline 180 & Tidak Terhubung & - \\
\hline 200 & Tidak Terhubung & - \\
\hline$>200$ & Tidak Terhubung & - \\
\hline
\end{tabular}

Selanjutnya dapat melakukan pengujian pada sensor. Pengujian pada sensor ini bertujuan mengetahui sensitifitas sensor terhadap suatu produk tertentu di depannya yang terdapat dalam ruangan. Sensor ini bekerja berdasarkan deteksi yang dilakukan oleh sensor. Data hasil pengujian sensor, sebagai berikut:

Tabel 2. Hasil Pengujian Jarak Deteksi Sensor

\begin{tabular}{|c|c|}
\hline Jarak Deteksi (cm) & Keterangan \\
\hline 10 & Mendeteksi \\
\hline 20 & Mendeteksi \\
\hline 30 & Mendeteksi \\
\hline 40 & Mendeteksi \\
\hline 50 & Mendeteksi \\
\hline 60 & Mendeteksi \\
\hline 70 & Tidak Mendeteksi \\
\hline 80 & Tidak Mendeteksi \\
\hline 90 & Tidak Mendeteksi \\
\hline 100 & Tidak Mendeteksi \\
\hline
\end{tabular}

Pengujian terhadap pencahayaan untuk mengetahui apakah cahaya mempengaruhi proses pemindaian. Pada proses peletakan Kode QR, pencahayaan dapat mempengaruhi proses pemindaian karena jika tempat tersebut kurang cahaya Kode QR tidak dapat dipindai melalui smartphone. Hasil pengujian pencahayaan dapat dilihat sebagai berikut:

Tabel 3. Pengujian Pencahayaan Pemindaian Kode QR

\begin{tabular}{|l|c|}
\hline \multicolumn{1}{|c|}{ Pencahayaan } & Hasil \\
\hline Sangat Gelap & Tidak Berhasil \\
\hline Gelap & Tidak Berhasil \\
\hline Redup & Berhasil \\
\hline Terang & Berhasil \\
\hline
\end{tabular}




\section{Jurnal Elektro Luceat [Juli] [2020]}

\begin{tabular}{|l|c|}
\hline Sangat Terang & Berhasil \\
\hline
\end{tabular}

Pengujian yang dilakukan terhadap QRCode scanner dilakukan untuk mengetahui kualitas dari quick response code scanner yang digunakan. Pengujian dilakukan dengan membandingkan antara kode asli dari quick response code dengan data yang ditampilkan. Dengan memasukan source code untuk barcode scanner ke Arduino yang dihubungkan melewati Arduino USB. Pengambilan data berguna untuk mengetahui seberapa banyak quick response code scanner dapat menscan quick response code dengan menentukan jarak antara quick response code scanner dan quick response code tersebut. Hasil pengujian dapat dilihat sebagai berikut:

Tabel 4. Jarak Kode $Q R$ dengan Scanner

\begin{tabular}{|c|c|c|c|}
\hline Jarak (cm) & Hasil & Waktu (Detik) & Total Kode QR \\
\hline \multirow{3}{*}{5} & \multirow{3}{*}{ Berhasil } & 10 & 4 \\
\hline & & 20 & 6 \\
\hline & & 30 & 11 \\
\hline \multirow{3}{*}{10} & \multirow{3}{*}{ Berhasil } & 10 & 3 \\
\hline & & 20 & 7 \\
\hline & & 30 & 12 \\
\hline \multirow{3}{*}{15} & \multirow{3}{*}{ Berhasil } & 10 & 5 \\
\hline & & 20 & 10 \\
\hline & & 30 & 15 \\
\hline \multirow{3}{*}{20} & \multirow{3}{*}{ Berhasil } & 10 & 6 \\
\hline & & 20 & 12 \\
\hline & & 30 & 15 \\
\hline \multirow{3}{*}{25} & \multirow{3}{*}{ Berhasil } & 10 & 7 \\
\hline & & 20 & 14 \\
\hline & & 30 & 16 \\
\hline
\end{tabular}

Data diatas berguna untuk mengetahui berapa jarak quick response code yang dapat terscan dalam selang jarak $5 \mathrm{~cm}, 10 \mathrm{~cm}, 15 \mathrm{~cm}, 20 \mathrm{~cm}$, dan $25 \mathrm{~cm}$. Setelah dilakukan pengujian dan pengambilan data serta hasil seperti tabel diatas maka pada jarak $5 \mathrm{~cm}, 10 \mathrm{~cm}, 15 \mathrm{~cm}, 20 \mathrm{~cm}$, dan $25 \mathrm{~cm}$ berhasil dan dapat terscan. Jarak $20 \mathrm{~cm}$ adalah yang paling baik karena dapat menscan paling banyak, baik dalam waktu 10 detik, 20 detik, maupun 30 detik.

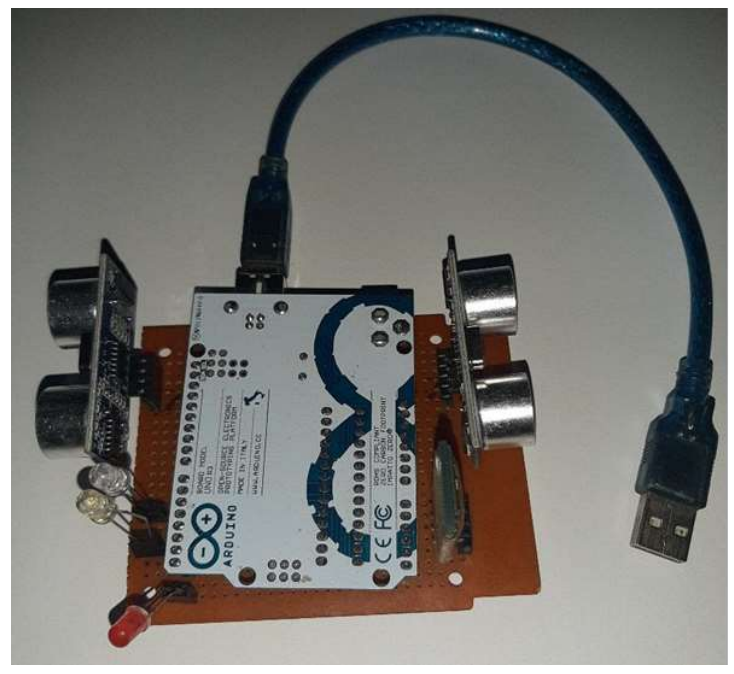

Gambar 8. Hasil Prototipe Alat 
Jurnal Elektro Luceat [Juli] [2020]

\section{KESIMPULAN}

Kesimpulan yang dapat diambil dari penelitian ini adalah :

1. Sistem yang dibuat membutuhkan suatu perangkat baik perangkat keras maupun perangkat lunak yaitu Mikrokontroler arduino, Sensor ultrasonic, Bluetooth, Kabel dan Arduino Konektor USB, PCB / Project Board, driver motor L298N, Android Development, C\# Language, Arduino Software IDE (Integrated Developtment Enviroenment). Perangkat bluetooth mengendalikan arduino secara otomatis dan sensor mendeteksi adanya objek maka tegangan output dari sensor akan masuk ke mikrokontroler, kemudian mikrokontroler melalui arduino akan memproses untuk mengaktifkan conveyor dan conveyor bergerak ketika produk terscan oleh quick response code scanner. Setelah semua input terpenuhi maka dibutuhkan sistem yang bisa diatur untuk mengeksekusi sebuah perintah menggunakan perangkat lunak.

2. Alat penghitung jumlah barang ini dapat mempercepat proses dalam pemasukkan data dan memudahkan menghitung jumlah barang yang masuk maupun keluar, dikarenakan alat ini secara otomatis akan menghitung dan memasukkan data dengan cara melakukan pemindaian kode QR. Dengan alat perhitungan jumlah barang ini pula dapat menghemat tenaga, menghemat waktu dan mengurangi kesalahan akibat human error yang terjadi akibat proses manual. Data dari kode QR akan ditampilkan dilayar komputer dan dapat dipantau melalui smartphone, sehingga dapat dipantau secara realtime. Perancangan sistem kode QR scanner berbasis android untuk meningkatkan efektifitas kinerja pada proses pemasukan dan pengeluaran barang atau outstock. Perancangan basis data barang setelah atau hasil scan serta membuat koneksi ke pusat penyimpanan data dapat dibuat dengan firebase sebagai pusat database.

3. Berdasarkan hasil pengujian maka didapatkan suatu hasil, yaitu. Kode QR Scanner berhasil dan dapat terpindai dengan jarak maksimal sejauh $25 \mathrm{~cm}$. Posisi jarak antara kode QR scanner yang baik adalah $20 \mathrm{~cm}$ dan $25 \mathrm{~cm}$ dikarenakan jumlah kode QR yang terscan dalam 10 sampai 30 detik paling banyak di banding jarak $5 \mathrm{~cm}, 10 \mathrm{~cm}$ dan $15 \mathrm{~cm}$. Sedangkan untuk jarak yang paling sedikit dalam melakukan pemindaian kode QR adalah jarak $5 \mathrm{~cm}$. Sensor dapat mendeteksi objek sejauh $60 \mathrm{~cm}$, sedangkan pada jarak $70 \mathrm{~cm}$ hingga $100 \mathrm{~cm}$ sensor tidak dapat mendeteksi objek. Pada pencahayaan sangat terang, terang dan redup kode QR berhasil dilakukan proses pemindaian oleh scanner, sedangkan pada posisi pencahayaan gelap dan sangat gelap pemindaian kode QR tidak berhasil dilakukan. Pada jangkauan jarak koneksi bluetooth dapat dikendalikan sepenuhnya dengan jarak jangkauan maksimal $160 \mathrm{~cm}$, untuk jarak antara $180 \mathrm{~cm}$ sampai dengan lebih dari jangkauan $200 \mathrm{~cm}$ akan mengalamai koneksi yang mana sinyalnya terputus sehingga alat tidak dapat dikendalikan lagi.

\section{DAFTAR PUSTAKA}

[1] Irianto, D. (2017). Industry 4.0; The Challenges of Tomorrow. Disampaikan pada Seminar Nasional Teknik Industri, Batu-Malang.

[2] Lee, J., Lapira, E., Bagheri, B., Kao, H., (2013). Recent Advances and Trends in Predictive Manufacturing Systems in Big Data Environment. Manuf. Lett. 1 (1), 38-41.

[3] Hermann, M., Pentek, T., \& Otto, B. (2016). Design Principles for Industrie 4.0 Scenarios. Presented at the 49th Hawaiian International Conference on Systems Science. 
JEC Vol. 6 No. 1

Jurnal Elektro Luceat [Juli $]$ [2020]

[4] R. Hafid Hardyanto. (2017). Konsep Internet Of Things Pada Pembelajaran Berbasis Web. Jurnal Dinamika Informatika Volume 6, No 1, Februari 2017 ISSN 1978-1660: 87 - 97 ISSN online 2549-8517

[5] Djuandi, Feri. (2011). Pengenalan Arduino. Jakarta: Penerbit Elexmedia.

[6] Artanto. (2012). Aplikasi Mikrokontroler ATMega8535 dan ATMega16. Yogyakarta: ANDI.

[7] B. Gustomo. (2015). Pengenalan Arduino Dan Pemrogrammannya. Bandung: Informatika Bandung.

[8] Soon, Tan Jin. (2008). QR Code. Singapore. Synteshis journal 2008.

[9] DENSO ADC. (2011). QR Code Essensials.Japan, DENSO Wave Incorporated. 